\begin{tabular}{|c|c|c|c|}
\hline $\begin{array}{l}\text { RESEARCH } \\
\text { ARTICLE }\end{array}$ & $\begin{array}{r}\text { ADVANCE RESEARCH JOURNAL OI } \\
\text { volume } 6 \mid \text { Issue } 2 \mid \text { December, } 2015 \mid 213-216\end{array}$ & SOCIAL SCIENCE & \\
\hline $0=$ & DOI: 10.15740/HAS/ARJSS/6.2/213-216 & Visit us : www.researchjournal.co.in & \\
\hline
\end{tabular}

\title{
A look into the household environment of female wheelchair users : An ergonomic approach
}

Deepika Bisht*, Muninder Kaur Sidhu and Sharanbir Kaur

Department of Family Resource Management, College of Home Science, Punjab Agricultural University, LUDHIANA (PUNJAB) INDIA

(Email : deepshelly@gmail.com)

\section{ARTICLE INFO :}

$\begin{array}{lll}\text { Received } & : & 26.09 .2015 \\ \text { Revised } & : & 05.11 .2015 \\ \text { Accepted } & : & 13.11 .2015\end{array}$

KEY WORDS :

Ergonomics, Household environment, Wheelchair users

\section{HOW TO CITE THIS ARTICLE :}

Bisht, Deepika, Sidhu , Muninder Kaur and Kaur, Sharanbir (2015). A look into the household environment of female wheelchair users : An ergonomic approach. Adv. Res. J. Soc. Sci., 6 (2) : 213-216.

*Author for correspondence

\begin{abstract}
Women are engaged in performing a number of household activities like working in kitchen, child care, clothing care and sorting out and storing almost all kind of household items. These activities require moving about the premises and carrying stuff from one place to other within the house. Disabled women are performing these activities in an environment which is not suitable for their changed bodily dimensions and conditions. Hence, they find it very difficult to work in this kind of environment especially when they need to stretch their body beyond their physical capabilities. So, the present study was planned to ergonomically evaluate the household environment (furniture, storage spaces and working centers) of the female wheelchair users of Punjab. Results revealed that there were no special provisions or workspace designing for the wheelchair users, regarding their limitations, to make their living and working comfortable in their houses.
\end{abstract}

